\title{
Antimicrobial activity of some essential oils against Streptococcus agalactiae, an important pathogen for fish farming in Brazil
}

\section{Cláudia Majolo, Fabiana Pilarski, Francisco Célio Maia Chaves, Humberto Ribeiro Bizzo \& Edsandra Campos Chagas}

To cite this article: Cláudia Majolo, Fabiana Pilarski, Francisco Célio Maia Chaves, Humberto Ribeiro Bizzo \& Edsandra Campos Chagas (2018) Antimicrobial activity of some essential oils against Streptococcus agalactiae, an important pathogen for fish farming in Brazil, Journal of Essential Oil Research, 30:5, 388-397, DOI: 10.1080/10412905.2018.1487343

To link to this article: https://doi.org/10.1080/10412905.2018.1487343

曲 Published online: 30 Jul 2018.

Submit your article to this journal $₫$

山 Article views: 133

View Crossmark data ¿ 


\title{
Antimicrobial activity of some essential oils against Streptococcus agalactiae, an important pathogen for fish farming in Brazil
}

\author{
Cláudia Majolo $\mathbb{D}^{\mathrm{a}}$, Fabiana Pilarski $\mathbb{D}^{\mathrm{b}}$, Francisco Célio Maia Chaves $\mathbb{( D}^{\mathrm{a}}$, Humberto Ribeiro Bizzo $\mathbb{D}^{\mathrm{c}}$ \\ and Edsandra Campos Chagas (1D ${ }^{a}$
}

${ }^{a}$ Embrapa Amazônia Ocidental, Amazonas, Brazil; bCentro de Aquicultura (CAUNESP), Universidade Estadual Paulista (UNESP), Jaboticabal, Brazil; 'Embrapa Agroindústria de Alimentos, Brazil, Rio de Janeiro

\section{ABSTRACT}

The antimicrobial activity of the essential oils from Lippia alba, Lippia sidoides, Mentha piperita, Ocimum gratissimum and Zingiber officinale was tested against Streptococcus agalactiae. The major compounds in the oils, identified by gas chromatography and mass spectrometry (GC/ MS), were geranial (25.4\%), neral (16.6\%) and caryophyllene oxide (16.0\%) in L. alba; thymol (76.6\%), $p$-cymene $(6.3 \%)$ and $\beta$-caryophyllene $(5.0 \%)$ in L. sidoides; menthol $(30.5 \%)$, menthyl acetate $(14.6 \%)$, pulegone $(14.2 \%)$ and menthone $(12.9 \%)$ in $M$. piperita; eugenol $(43.3 \%), 1,8$ cineole $(28.2 \%)$ and $\beta$-selinene (5.5\%) in O. gratissimum; and geranial (23.2\%), neral (16.7\%) and 1,8-cineole (15.8\%) in Z. officinale. All essential oils evaluated showed bactericidal action against S. agalactiae with minimum inhibitory concentration (MIC) ranging from $312.5-2,500 \mu \mathrm{gL}^{-1}$ and minimum bactericidal concentration (MBC) ranging from $416.7-2,500 \mu \mathrm{g} \mathrm{mL}^{-1}$. In this study, L. sidoides essential oil showed the better results against $S$. agalactiae.

\section{ARTICLE HISTORY}

Received 19 August 2016

Accepted 6 June 2018

\section{KEYWORDS}

Medicinal plants; essential oil composition; antimicrobial activity; group B Streptococcus

\section{Introduction}

Bacterioses are a limiting factor in fish farming, decreasing productivity, delaying fish growth and causing mortality in the world of aquaculture (1). The etiologic agents of disease in farmed fish in Brazil are Aeromonas hydrophila, Flavobacterium columnare and Streptococcus sp (2-5). The most commonly encountered Streptococcus species in fish is Streptococcus agalactiae, isolated from outbreaks in Nile Tilapia (Oreochromis niloticus) cultured in Brazil (2). This pathogen is frequently associated with meningoencephalitis and septicemia $(6,7)$.

Antibiotics are commonly used for the treatment of bacterial diseases in aquaculture systems (1). However, the frequent use of antibiotics can lead to drug-resistant bacteria selection $(8,9)$. Thus, essential oils and extracts from plants represent an alternative for the control of fish diseases $(10,11)$. To evaluate this possibility, the essential oils of five different plants were tested. These species were selected since they are cultivated, easily obtained and used for food flavouring locally, and all have been reported as presenting antimicrobial properties.

The Lippia genus has about 200 species $(12,13)$. Lippia alba ('erva-cidreira') is native to Brazil and the major compounds in its essential oil are citral, carvone and linalool $(14,15)$. Lippia sidoides (pepper-rosmarin) exhibits in its essential oil up to $60 \%$ of thymol or mixtures of thymol and carvacrol $(16,17)$. These Lippia species showed anaesthetic, antimicrobial and anti-parasitic activity (18-23).

Mentha piperita (peppermint) is an aromatic species from Europe and its essential oil contains menthol, menthofuran and pulegone as the main components. Antioxidant, immunostimulants, anti-parasitic and antimicrobial properties against Gram-positive and Gram-negative bacteria have been described (21,24-27).

Ocimum gratissimum (clove basil) is widely distributed in tropical regions and the major compound in the essential oil is eugenol. The oil was described as anesthetic, immunostimulant and anti-parasitic (2830). The antimicrobial activity of O. gratissimum against $A$. hydrophila was registered by Sutili et al. (31).

Zingiber officinale (ginger) essential oil is rich in geranial, neral, cineole, borneol, zingiberene and bisabolene (32-34). Anti-inflammatory, antifungal, immunostimulants and antimicrobial activities were described for this oil (35-37). Ginger oil was shown to be effective against Escherichia coli, Salmonella typhi and Staphylococcus aureus $(38,39)$.

In this study, the chemical composition of the essential oils from L. alba, L. sidoides, M. piperita, O. 
gratissimum and Z. officinale was investigated, as well as their antimicrobial activity against $S$. agalactiae.

\section{Materials and methods}

\section{Plant material}

L. alba, L. sidoides, M. piperita, O. gratissimum and $Z$. officinale specimens were grown in the Medical Plant Collection of Embrapa Amazônia Ocidental in Manaus, Amazonas State, Brazil. The plants were identified and deposited in the IAN Herbarium of the Botany Laboratory of Embrapa Amazônia Oriental, Belém, in Pará State. After harvest in March 2016, the parts of the plants (leaves and inflorescences or rhizomes) were collected and dried at room temperature, in an open shed, in the shade and then stored for essential oil distillation.

\section{Essential oil distillation}

Essential oils from L. alba, L. sidoides, M. piperita, O. gratissimum and $Z$. officinale were obtained by hydrodistillation in a Clevenger-type apparatus for $2 \mathrm{~h}$. In each distillation, $500 \mathrm{~g}$ of leaves and inflorescences or rhizomes were used. The essential oils collected were stored at $4^{\circ} \mathrm{C}$ until analysis. For use, the essential oils were dissolved in dimethylsulfoxide - DMSO (1:4) to prepare stock solutions, which were sterilized by filtration through a $0.22 \mu \mathrm{m}$ membrane filter.

\section{Essential oil composition}

The chemical components of $L$. alba, L. sidoides, $M$. piperita, O. gratissimum and Z. officinale essential oils were analysed by gas chromatography (GC), and GC coupled to mass spectrometry (MS). Analyses were performed in an Agilent (Palo Alto, USA) 7890A gas chromatograph fitted with a 5\% phenyl/95\% methyl silicone (HP5, $30 \mathrm{~m} \times 0.25 \mathrm{~mm} \times 0.25 \mathrm{~mm}$ ) fused silica capillary column. Oven temperature was programmed to increase from $60^{\circ} \mathrm{C}$ to $240^{\circ} \mathrm{C}$ at $3^{\circ} \mathrm{C}$ minutes ${ }^{-1}$. Hydrogen was used as carrier gas $\left(1.4 \mathrm{~mL}^{\text {minutes }}{ }^{-1}\right)$. The oils were diluted to $1 \%$ in dichloromethane and $1.0 \mathrm{~mL}$ of this solution was injected in split mode (1:100). The injector was kept at $250^{\circ} \mathrm{C}$ and the flame ionization detector (FID) at $280^{\circ} \mathrm{C}$.

Mass spectra were obtained in an Agilent $5973 \mathrm{~N}$ MSD system operating in electronic ionization mode (EI) at $70 \mathrm{eV}$, with scan mass range of $40-500 \mathrm{~m} \mathrm{z}^{-1}$. The sampling rate was 3.15 scans s$^{-1}$. The ion source was kept at $230^{\circ} \mathrm{C}$, mass analyser at $150^{\circ} \mathrm{C}$ and transfer line at $260^{\circ} \mathrm{C}$. All chromatographies were the same as described above. Helium was used as carrier gas $\left(1.0 \mathrm{~mL}\right.$ minutes $\left.^{-1}\right)$.

Linear retention indices were calculated by injecting a series of n-alkanes (C7-C26) into the same column, adopting the conditions used for GC analyses. Oil components were identified by a computer search using the 6th edition of the Wiley Registry of Mass Spectral Data, and comparison between calculated linear retention indices and data from the literature (40).

\section{Antimicrobial activity}

\section{Microorganisms and culture conditions}

The bacterium S. agalactiae (KJ561060) was isolated from a diseased tilapia (Oreochromis niloticus) at Aquaculture Center of the Paulista State University (CAUNESP), Jaboticabal, SP. The strain was stored in BHI (brain heart infusion, Himedia, Mumbai, India) supplemented with $30 \%$ sterile glycerol at $-80^{\circ} \mathrm{C}$ in the Laboratory of Fish Culture at Embrapa Amazônia Ocidental. For reactivation, the strain was plated on TSA (trypticase soy agar, Himedia, Mumbai, India) supplemented with 5\% sheep blood agar and incubated for $48 \mathrm{~h}$ at $35^{\circ} \mathrm{C}$. Verification of strain purity was accomplished by Gram staining and visualization under a light microscope $(1000 \times$ magnification $)$.

\section{Antimicrobial assay}

Antimicrobial activity was assayed by broth microdilution method according to procedures using 96-well plates, described by Clinical Laboratory Standard Institute (M7-A6) (41). Medium without inoculum or essential oils were used as negative controls, and medium with inoculum was used as positive control, under the same conditions. Cloramphenicol (Flucka BioChemika, St. Gallen, Switzerland) was used as positive control against bacteria $\left(0.2 \mu \mathrm{g} \quad \mathrm{mL}^{-1}\right)$. Microdilutions were performed for each oil type at final concentrations of 20,000, 10,000,5,000, 2,500, $1,250,625$ and $312.5 \mu \mathrm{g} \mathrm{mL}{ }^{-1}$.

The results were based on visual growth of microorganism, which was confirmed by aseptical addition of the sterile aqueous solution of $0.5 \%$ triphenyl tetrazolium chloride (TTC) to the plate-wells and incubated at $35^{\circ} \mathrm{C}$ for $1 \mathrm{~h}$. Results were obtained in triplicate and expressed as minimum inhibitory concentration (MIC), defined as the lowest concentration of an antimicrobial that will inhibit the visible growth of a microorganism after $24 \mathrm{~h}$ of incubation. Bactericidal action of the essential oil were evaluated by adding 20 $\mu \mathrm{L}$ of the microbial culture, removed from wells with 
concentrations equal to or higher than the MIC, inoculated on Mueller Hinton agar plates and incubated at $35^{\circ} \mathrm{C}$ for $24 \mathrm{~h}$. After incubation, the plates were read and minimum bacterial concentration (MBC) was assigned to the lowest concentration without bacterial growth. Experiments were conducted in triplicate.

\section{Statistical analysis}

Data on MIC and MBC were evaluated by ANOVA and Tukey's test $(p<0.05)$ to compare the action of the essential oil plant species evaluated against $S$. agalactiae.

\section{Results and discussion}

\section{Essential oil composition}

The essential oil yields for $L$. alba, L. sidoides, $M$. piperita, O. gratissimum and Z. officinale were $0.30 \%$, $4.36 \%, 1.10 \%, 2.36 \%$ and $0.68 \%$, respectively. The chromatographic profiles of the essential oils are shown in Figures 1-5 and the chemical composition in Table 1.

Forty-seven compounds were identified represented in the essential oil of L. alba, accounting for $89.5 \%$ of the oil composition, with geranial (25.4\%), neral (16.6\%) and caryophyllene oxide (16.0\%) predominating. The monoterpenes geranial and neral are the main constituents of the citral chemotype
$(14,15)$. The main reason to variations on chemical constituents of $L$. alba essential oil is attributed to genetic factors $(14,15)$.

In the essential oil of $L$. sidoides, twenty-one compounds were identified, accounting for $98.6 \%$ of its essential oil composition. The major compounds were thymol (76.6\%), $p$-cymene $(6.3 \%)$ and $\beta$-caryophyllene (5.0\%). This profile was confirmed in others studies, with some variations in oil component proportions $(42,43)$. The variations in content of $L$. sidoides essential oil are attributed to age and have low genetic control (43).

Nineteen compounds were identified in the essential oil of $M$. piperita, comprising $93.8 \%$ of the oil composition. Quantitatively, the most abundant were menthol (30.5\%), menthyl acetate (14.6\%), pulegone (14.2\%) and menthone (12.9\%). Similar results were observed for African peppermint essential oil, in which major compounds were menthol (39.3\%) and menthone $(25.2 \%)$, although the contents were higher than observed in our study (44).

In the essential oil of O. gratissimum, eighteen compounds were identified, accounting for $97.1 \%$ of the oil composition. The major compounds were eugenol (43.3\%), 1,8-cineole (28.2\%) and $\beta$-selinene (5.5\%). Other reports have shown that chemical composition percentages of O. gratissimum were higher than ours with eugenol $(68.8 \%)$ followed by methyl eugenol (13.2\%) (45).

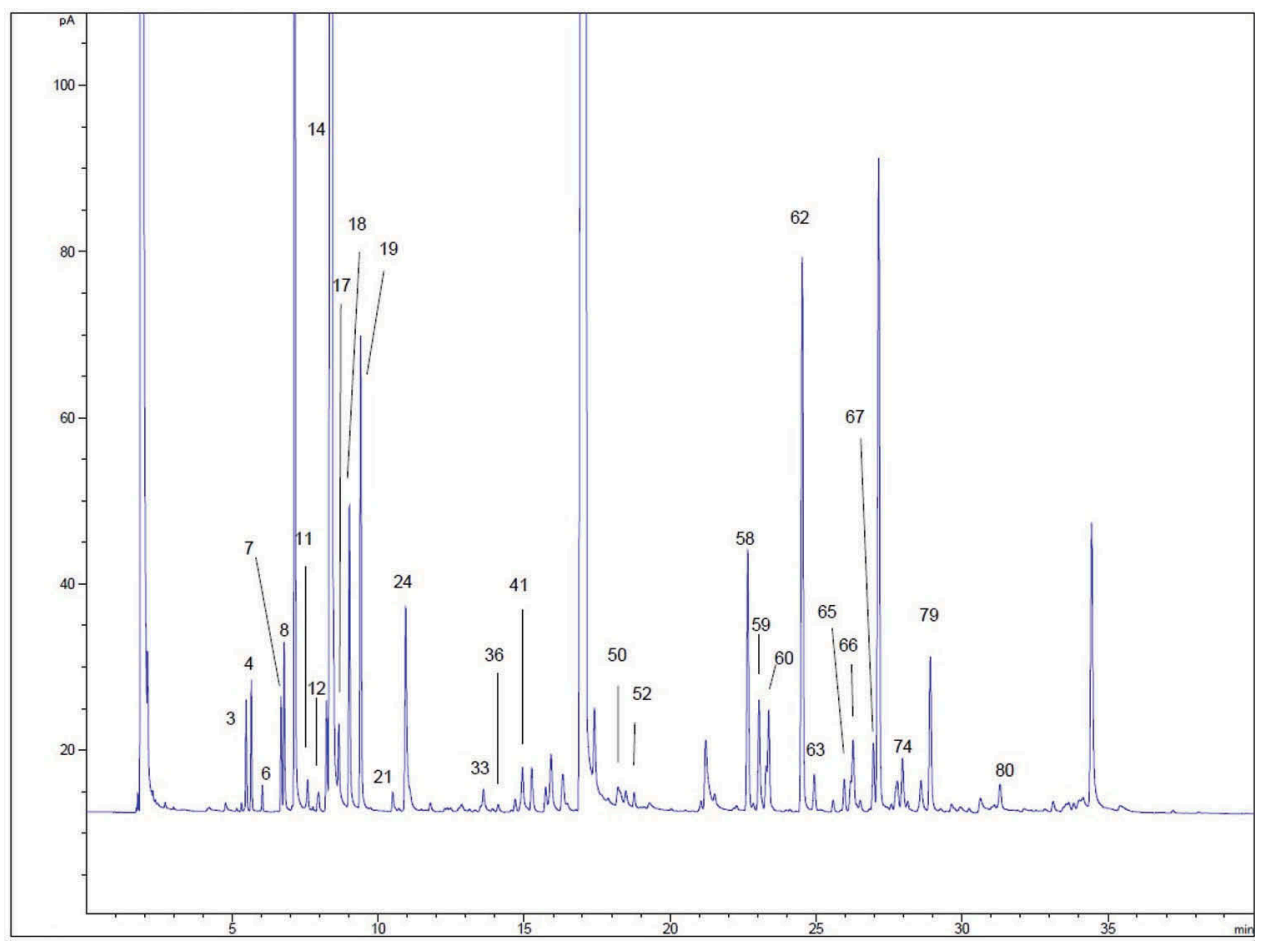

Figure 1. GC chromatogram of essential oil from Lippia alba. 


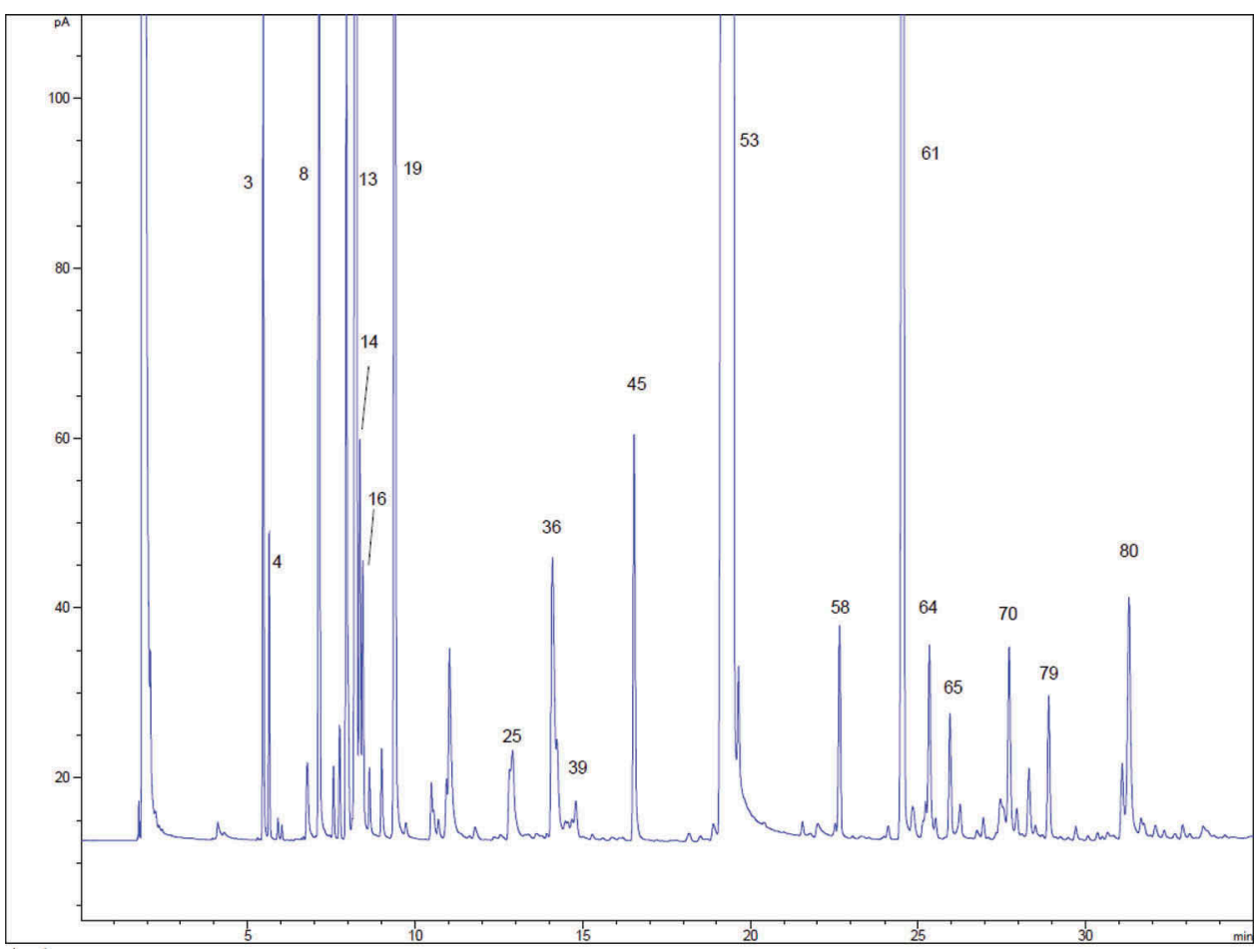

Figure 2. GC chromatogram of essential oil from Lippia sidoides.

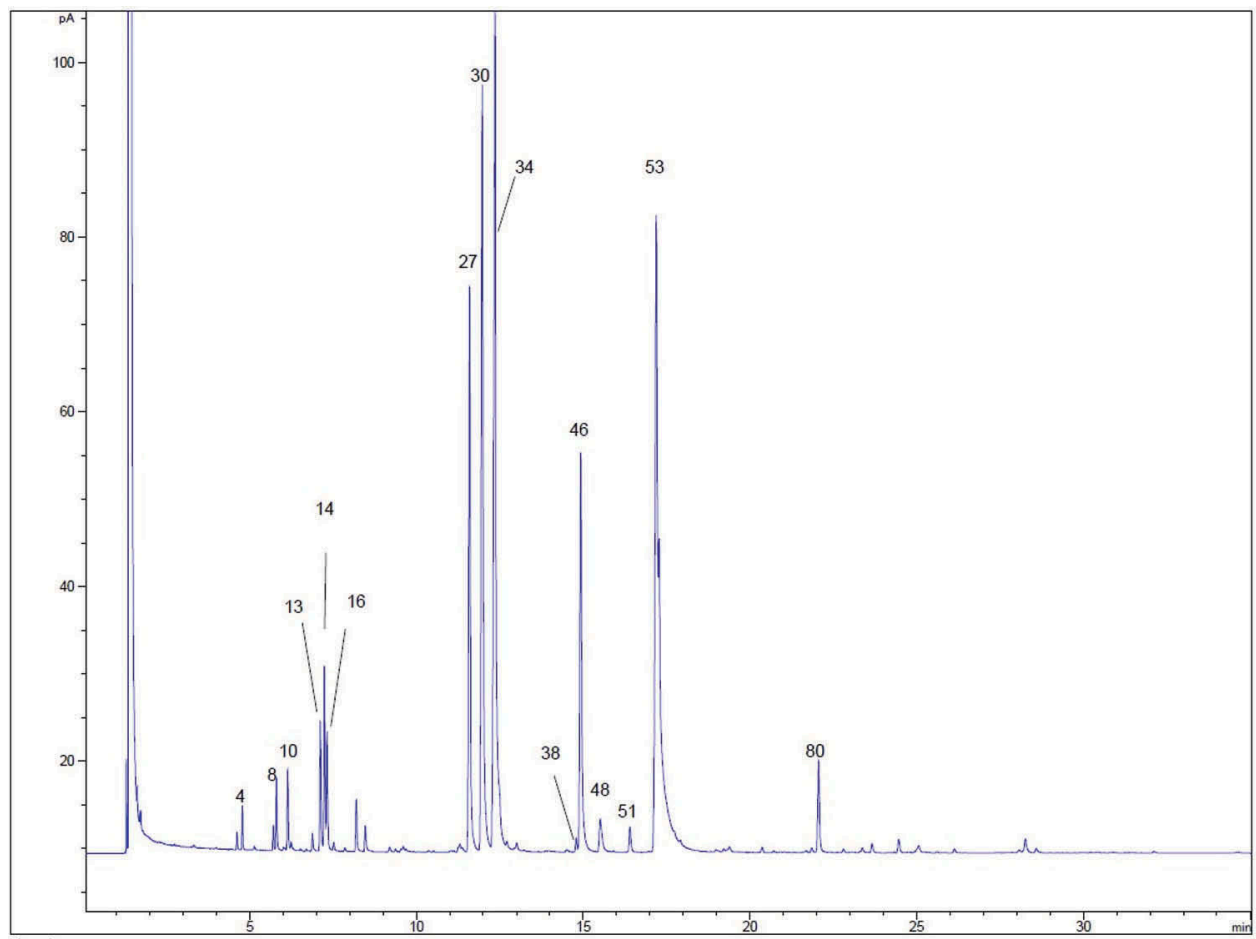

Figure 3. GC chromatogram of essential oil from Mentha piperita.

Twenty-seven compounds were identified in the essential oil of $Z$. officinale, comprising $98.9 \%$ of the oil composition. The main compounds were geranial (23.2\%), neral (16.7\%) and 1,8-cineole (15.8\%) and in minor levels, $\alpha$-zingiberene $(2.1 \%), \quad \beta$ - sesquiphellandrene (1.1\%) and ar-curcumene (1.0\%). However, in the commercial ginger essential oil, the compounds geranial, neral, a-curcumene and 1,8cineol were not found, but they were present in this study. The dominant components of this commercial 


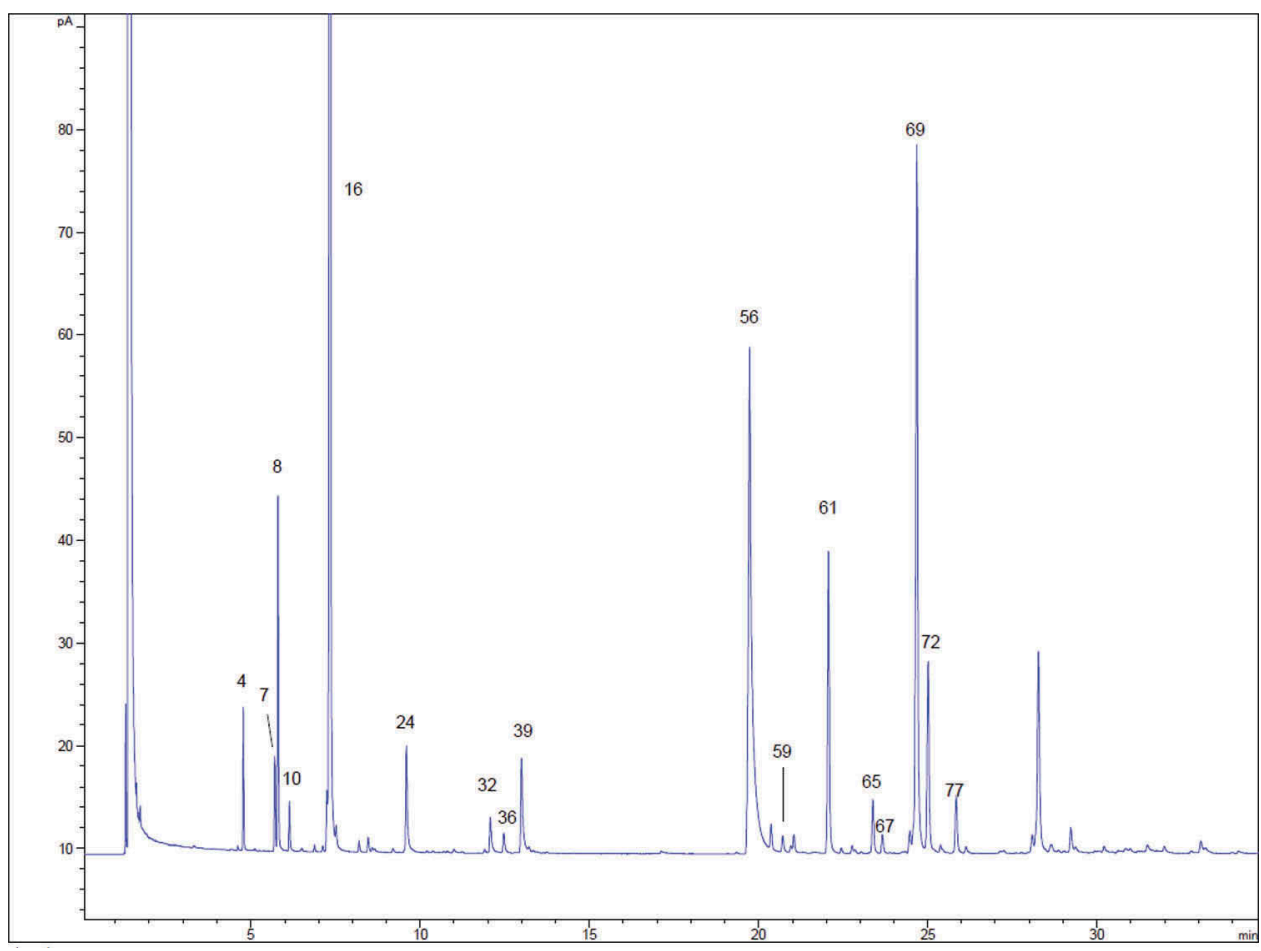

Figure 4. GC chromatogram of essential oil from Ocimum gratissimum.

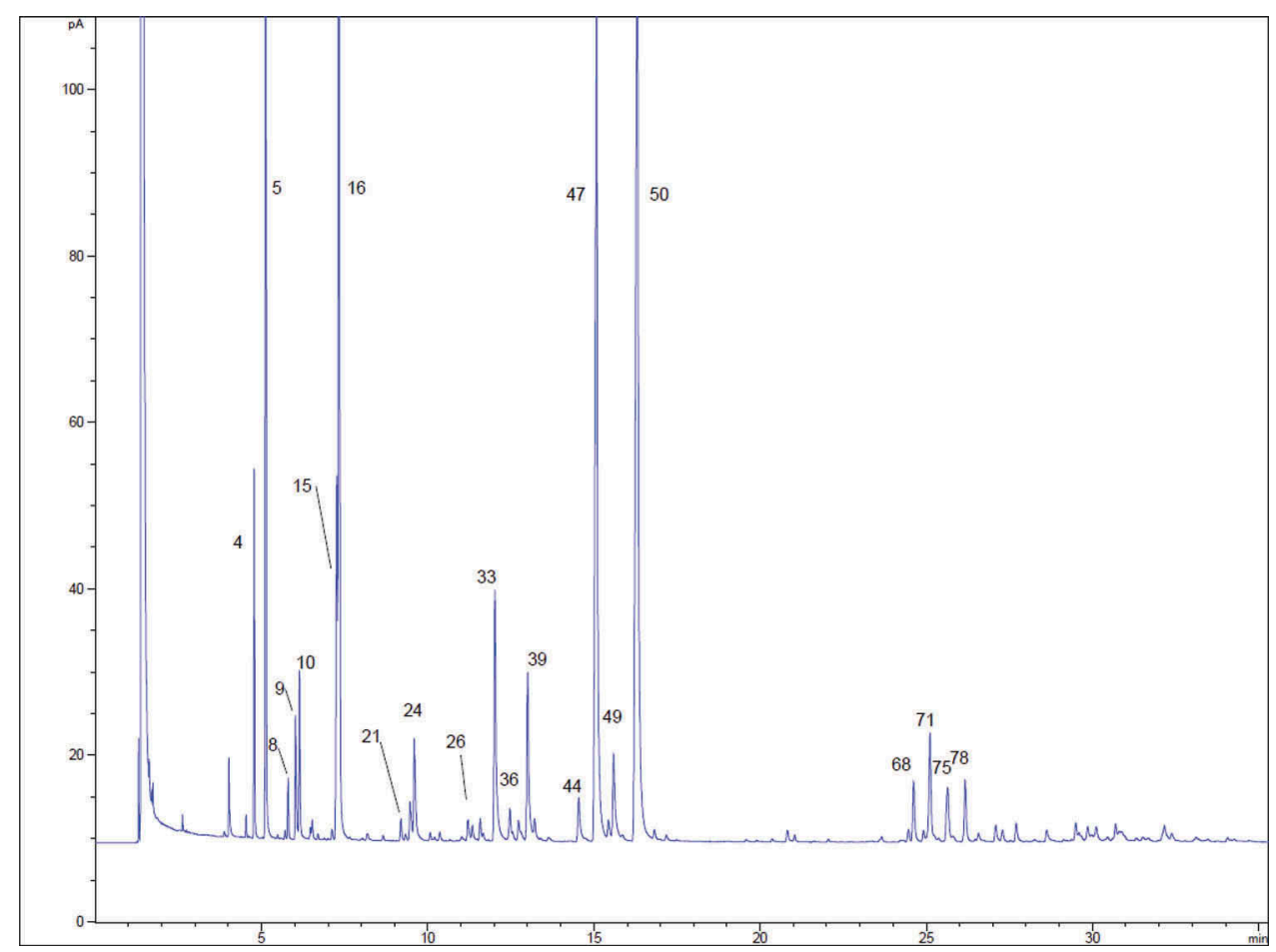

Figure 5. GC chromatogram of essential oil from Zingiber officinale.

ginger are zingiberene, $\beta$-bisabolene, $\beta$-sesquiphellandrene and $<$ ar $>$ curcumene, and these compounds are identified in this study at minor proportions (33).
In general, several factors affect both the yield and composition of essential oils, including geographical origin, climate conditions, seasonality, stage of plant 
Table 1. Chemical composition (\%) of Lippia alba, Lippia sidoides, Mentha piperita, Ocimum gratissimum and Zingiber officinale essential oils.

\begin{tabular}{|c|c|c|c|c|c|c|c|c|}
\hline & Components & L. alba & L. sidoides & M. piperita & 0. gratissimum & Z. officinale & $\mathrm{Al}$ & $\mathrm{RI}^{*}$ \\
\hline 1 & 2-heptanone & - & - & - & - & 1.0 & 889 & 890 \\
\hline 2 & tricyclene & - & - & - & - & 0.3 & 921 & 922 \\
\hline 3 & a-thujene & 0.2 & 0.3 & - & - & - & 924 & 929 \\
\hline 4 & a-pinene & 0.3 & 0.1 & 0.3 & - & 2.9 & 932 & 932 \\
\hline 5 & camphene & - & - & - & - & 11.3 & 946 & 947 \\
\hline 6 & benzaldehyde & 0.2 & - & - & - & - & 952 & 965 \\
\hline 7 & sabinene & 0.1 & - & - & 0.7 & - & 969 & 975 \\
\hline 8 & $\beta$-pinene & 0.4 & - & 0.6 & 2.8 & 0.6 & 974 & 976 \\
\hline 9 & 6-methyl-5-hepten-2-one & - & - & - & - & 1.2 & 981 & 985 \\
\hline 10 & myrcene & 2.0 & 1.1 & 0.4 & 0.7 & 1.8 & 988 & 988 \\
\hline 11 & a-phellandrene & 0.5 & - & - & - & 0.3 & 1002 & 1005 \\
\hline 12 & a-terpinene & 0.3 & 0.7 & - & - & - & 1014 & 1019 \\
\hline 13 & p-cymene & 0.7 & 6.3 & 0.3 & - & - & 1020 & 1022 \\
\hline 14 & limonene & - & 0.4 & 3.2 & - & - & 1024 & 1025 \\
\hline 15 & $\beta$-felandrene & - & - & - & - & 4.0 & 1025 & 1028 \\
\hline 16 & 1,8-cineole & - & 0.7 & 1.6 & 28.2 & 15.8 & 1026 & 1030 \\
\hline 17 & cis-ocimene & 0.6 & - & - & 3.7 & - & 1032 & 1038 \\
\hline 18 & trans-ocimene & 0.3 & - & - & - & - & 1044 & 1052 \\
\hline 19 & $\gamma$-terpinene & 0.4 & 2.0 & - & - & - & 1054 & 1061 \\
\hline 20 & cis-sabinene hydrate & 0.2 & - & - & - & - & 1065 & 1071 \\
\hline 21 & terpinolene & - & - & - & - & 0.3 & 1086 & 1088 \\
\hline 22 & p-cymenene & 0.7 & - & - & - & - & 1089 & 1091 \\
\hline 23 & epoxy myrcene & 0.5 & - & - & - & - & 1090 & 1095 \\
\hline 24 & linalool & 1.5 & - & - & 1.3 & 1.8 & 1095 & 1100 \\
\hline 25 & ipsdienol & - & 0.6 & - & - & - & 1140 & 1148 \\
\hline 26 & camphor & 0.3 & - & - & - & 0.4 & 1141 & 1142 \\
\hline 27 & menthone & - & - & 12.9 & - & - & 1148 & 1151 \\
\hline 28 & citronellal & - & - & - & - & 0.3 & 1148 & 1152 \\
\hline 29 & methyl campheniol & 0.2 & - & & - & - & & 1154 \\
\hline 30 & menthofurane & - & - & 1.5 & - & - & 1159 & 1160 \\
\hline 31 & neo-menthol & - & - & 2.4 & - & - & 1161 & 1163 \\
\hline 32 & $\delta$-terpineol & - & - & - & 0.4 & - & 1162 & 1166 \\
\hline 33 & borneol & 0.3 & - & - & - & 4.3 & 1165 & 1164 \\
\hline 34 & menthol & - & - & 30.5 & - & - & 1167 & 1175 \\
\hline 35 & umbelulone & - & 0.2 & - & - & - & 1167 & 1176 \\
\hline 36 & terpinen-4-ol & 1.2 & 1.0 & - & 0.4 & 0.6 & 1174 & 1178 \\
\hline 37 & (E)-isocitral & - & - & - & - & 0.5 & 1177 & 1182 \\
\hline 38 & neo-isomenthol & - & - & 1.0 & - & - & 1184 & 1190 \\
\hline 39 & a-terpineol & - & 0.2 & - & 1.1 & 2.8 & 1186 & 1190 \\
\hline 40 & myrtenal & - & - & - & - & 0.5 & 1195 & 1190 \\
\hline 41 & trans-dihydrocarvone & 0.5 & - & - & - & - & 1200 & 1197 \\
\hline 42 & $\beta$-fenchyl alcohol & 0.2 & - & - & - & - & & 1208 \\
\hline 43 & citronellol & - & - & - & - & 1.0 & 1223 & 1228 \\
\hline 44 & nerol & 0.2 & - & - & - & - & 1227 & 1231 \\
\hline 45 & thymol methyl ether & 0.6 & 1.0 & - & - & - & 1232 & 1236 \\
\hline 46 & pulegone & - & - & 14.2 & - & - & 1233 & 1237 \\
\hline 47 & neral & 16.6 & - & - & - & 16.7 & 1235 & 1242 \\
\hline 48 & piperitone & - & - & 1.5 & - & - & 1249 & 1250 \\
\hline 49 & geraniol & 0.2 & - & - & - & 1.9 & 1249 & 1254 \\
\hline 50 & geranial & 25.4 & - & - & - & 23.2 & 1264 & 1272 \\
\hline 51 & neo-menthyl acetate & - & - & 0.8 & - & - & 1271 & 1271 \\
\hline 52 & bornyl acetate & 0.3 & - & - & - & - & 1287 & 1289 \\
\hline 53 & thymol & - & 76.6 & - & - & - & 1289 & 1296 \\
\hline 54 & menthyl acetate & - & - & 14.6 & - & - & 1294 & 1292 \\
\hline 55 & $\beta$-cubebene & 0.2 & - & - & - & - & 1387 & 1289 \\
\hline 56 & eugenol & 0.1 & - & - & 43.3 & - & 1357 & 1357 \\
\hline 57 & cyclosativene & 0.2 & - & - & - & - & 1369 & 1370 \\
\hline 58 & a-copaene & 1.0 & 0.4 & - & - & - & 1374 & 1375 \\
\hline 59 & $\beta$-bourbonene & 0.2 & - & - & 0.9 & - & 1387 & 1381 \\
\hline 60 & $\beta$-elemene & 2.0 & - & - & 0.8 & - & 1389 & 1389 \\
\hline 61 & (E)-caryophyllene & - & - & 0.3 & 3.7 & - & 1417 & 1415 \\
\hline 62 & $\beta$-caryophyllene & 6.6 & 5.0 & - & - & - & & 1417 \\
\hline 63 & $\beta$-gurjunene & 0.4 & - & - & - & - & 1431 & 1431 \\
\hline 64 & aromadendrene & 0.5 & 0.4 & - & - & - & 1439 & 1436 \\
\hline 65 & a-humulene & 0.6 & 0.3 & - & 0.6 & - & 1452 & 1450 \\
\hline 66 & allo-aromadendrene & 0.7 & - & - & & - & 1458 & 1460 \\
\hline 67 & $\gamma$-muurolene & 0.2 & - & - & 0.9 & - & 1478 & 1477 \\
\hline 68 & ar-curcumene & - & - & - & - & 1.0 & 1479 & 1481 \\
\hline 69 & $\beta$-selinene & 1.7 & - & - & 5.5 & - & 1489 & 1482 \\
\hline 70 & ledene & - & 0.3 & - & - & - & & 1492 \\
\hline
\end{tabular}


Table 1. (Continued).

\begin{tabular}{|c|c|c|c|c|c|c|c|c|}
\hline & Components & L. alba & L. sidoides & M. piperita & O. gratissimum & Z. officinale & $\mathrm{Al}$ & $\mathrm{RI}^{*}$ \\
\hline 71 & a-zingiberene & - & - & - & - & 2.1 & 1493 & 1494 \\
\hline 72 & a-selinene & 1.3 & - & - & 1.7 & - & 1498 & 1496 \\
\hline 73 & menthalactone & - & - & 5.3 & - & - & & 1495 \\
\hline 74 & a-muurolene & 0.4 & - & - & - & - & 1500 & 1501 \\
\hline 75 & $(E, E)$-a-farnesene & - & - & - & - & 1.2 & 1505 & 1508 \\
\hline 76 & $\gamma$-cadinene & 0.2 & - & - & - & - & 1513 & 1505 \\
\hline 77 & 7-epi-a-selinene & - & - & - & 0.4 & - & 1520 & 1513 \\
\hline 78 & $\beta$-sesquiphellandrene & - & - & - & - & 1.1 & 1521 & 1522 \\
\hline 79 & $\delta$-cadinene & 1.2 & 0.3 & - & - & - & 1522 & 1521 \\
\hline 80 & caryophyllene oxide & 16.0 & 0.7 & 0.4 & - & - & 1582 & 1572 \\
\hline 81 & viridiflorol & - & - & 2.0 & - & - & 1592 & 1584 \\
\hline \multirow[t]{2}{*}{82} & humulene epoxide II & 1.1 & - & & - & - & 1608 & 1612 \\
\hline & Total identified & 89.5 & 98.6 & 93.8 & 97.1 & 98.9 & & \\
\hline
\end{tabular}

Note: $\mathrm{Rl}=$ Retention Index in $\mathrm{HP}-5, \mathrm{Al}=$ Arithmetic Index.

development, procedures adopted for plant processing and oil extraction, and plant chemotype (46).

\section{Antimicrobial activity}

Essential oils of L. alba, L. sidoides, M. piperita, O. gratissimum and $Z$. officinale showed antimicrobial activity against $S$. agalactiae, with MIC ranging from 312.5-2,500 $\mu \mathrm{g} \mathrm{mL}^{-1}$ and MBC from 416.7-2,500 $\mu \mathrm{g}$ $\mathrm{mL}^{-1}$ (Table 2). It was demonstrated that all essential oils evaluated showed bactericidal activity against $S$. agalactiae.

The highest antimicrobial activity was exhibited by L. sidoides essential oil ( $\mathrm{MIC}=312.5 \mu \mathrm{g} \mathrm{mL} \mathrm{m}^{-1}$ and $\left.\mathrm{MBC}=416.7 \mu \mathrm{g} \mathrm{mL}^{-1}\right)$, and the lowest activity by $O$. gratissimum essential oil (MIC $=2,500 \mu \mathrm{g} \mathrm{mL}^{-1}$ and $\mathrm{MBC}=2,500 \mu \mathrm{g} \mathrm{mL}^{-1}$ ). Therefore, the most effective oil against $S$. agalactiae was $L$. sidoides, followed by $Z$. officinale, M. piperita, L. alba and O. gratissimum (Table 2).

The essential oil of $L$. alba at a concentration of 1,666.7 $\mu \mathrm{g} \mathrm{mL} \mathrm{m}^{-1}$ inhibited S. agalactiae growth. Sutili et al. (47) and Majolo et al. (22) described the bacteriostatic and bactericidal activity of $L$. alba against Gram-negative bacteria such as A. hydrophila. In the present study, this oil was effective against $S$. agalactiae, which is Gram-positive. The essential oil of another Lippia species, L. sidoides, showed the highest activity

Table 2. Antimicrobial activity of essential oils of bioactive plants.

\begin{tabular}{lcc}
\hline Species & $\mathrm{MIC}\left(\mu \mathrm{g} \cdot \mathrm{mL}^{-1}\right)$ & $\mathrm{MBC}\left(\mu \mathrm{g} \cdot \mathrm{mL}^{-1}\right)$ \\
\hline Lippia alba & $1,666.7 \pm 721.7 \mathrm{ab}$ & $1,666.7 \pm 721.7 \mathrm{ab}$ \\
Lippia sidoides & $312.5 \pm 0.0 \mathrm{~b}$ & $416.7 \pm 180.4 \mathrm{~b}$ \\
Mentha piperita & $1,250 \pm 0.0 \mathrm{ab}$ & $1,250 \pm 0.0 \mathrm{ab}$ \\
Ocimum gratissimum & $2,500 \pm 0.0 \mathrm{a}$ & $2,500 \pm 0.0 \mathrm{a}$ \\
Zingiber officinalis & $625 \pm 0.0 \mathrm{ab}$ & $833.3 \pm 360.8 \mathrm{ab}$ \\
\hline
\end{tabular}

Note: Values are given as mean \pm SD. Means followed by different letter in a column differs statistically by Tukey test $(p<0.05)$. MIC $=$ minimum inhibitory concentration, $\mathrm{MBC}=$ minimum bactericidal concentration against $S$. agalactiae. Similar results were observed by Majolo et al. (22) in tests against A. hydrophila, where they attributed the effect to the thymol contained in the oil. A stronger antimicrobial action can be obtained using isolated oil compounds, as shown by Heo et al. (48), who obtained MIC from $10-80 \mu \mathrm{g} \mathrm{mL}^{-1}$ using thymol against $A$. salmonicida. Earlier investigations corroborate the antimicrobial activity of essential oil of Lippia species (L. origanoides, $L$. aff. gracillis and $L$. grandis) against Gram-negative and Gram-positive bacteria, but these reports indicating that Gram-positive bacteria are more sensitive to the essential oils compared to Gram-negative bacteria (49-51).

The MIC obtained with $M$. piperita essential oil was $1,250 \mu \mathrm{g} \mathrm{ml}^{-1}$. Mahboubi \& Kazempour (26) found high activity of $M$. piperita essential oil against Grampositive and Gram-negative bacteria, and the oil they tested had similar composition to that identified in the present study, with menthol (36.9\%), menthone (28.8\%) and methyl acetate $(4.5 \%)$ as the main components. Menthol isolated from M. piperita was found to have high antimicrobial activity against seven microorganisms, the highest inhibitory effect being observed against Streptococcus mutans (52). In an investigation of the antimicrobial potential of other Mentha species using the disc diffusion method, Stanisavljević et al. (53) found a significant inhibitory effect of $M$. longifolia essential oil against the Gram-positive bacteria Bacillus subtilis, Micrococcus luteus and Enterococcus faecalis.

The MIC of O. gratissimum essential oil against $S$. agalactiae was $3,200 \mu \mathrm{g} \mathrm{ml}{ }^{-1}$. Other studies showed higher antimicrobial activity of $O$. gratissimum essential oil against both Gram-positive (S. aureus, Bacillus spp.) and Gram-negative bacteria (E. coli, Pseudomonas aeruginosae, S. typhi, Klebisiella pneumoniae, Proteus mirabilis) (45). Sutili et al. (31) found O. gratissimum essential oil MIC from 200-1,600 $\mu \mathrm{g} \mathrm{ml}^{-1}$ against the Gram-negative bacteria A. hydrophila. For commercial 
isolated eugenol, MIC ranged from 1,600-3,200 $\mu \mathrm{g} \mathrm{ml}^{-1}$ (54), which is similar to the value obtained for $S$. agalactiae treated with $O$. gratissimum essential oil containing eugenol as the major compound (43.3\%). The mechanism action of eugenol involves the rapid inhibition of the energy metabolism of Gram-positive bacteria (55).

Essential oil of $Z$. officinale also showed antimicrobial action against $S$. agalactiae, with MIC of $625 \mu \mathrm{g}$ $\mathrm{ml}^{-1}$ and MCB of $833.3 \mu \mathrm{g} \mathrm{ml}^{-1}$. Moderate activity of essential oil of $Z$. officinale var. rubrum Theilade was observed against the Gram-positive bacteria Bacillus licheniformis, Bacillus spizizenii and S. aureus and the Gram-negative bacteria E. coli, K. pneumoniae and Pseudomonas stutzeri. The major components of essential oil extracted from $Z$. officinale rhizomes are camphene (14.5\%), geranial (14.3\%) and geranyl acetate (13.7\%) (56). The antimicrobial activity of $Z$. officinale is attributed to components such as zingiberene and geranial (57). In the present study, the major compounds of $Z$. officinale essential oil were geranial (23.2\%), neral (16.7\%) and 1,8-cineol (15.8\%), as well as $\alpha$-zingiberene $(2.1 \%)$ at minor levels, and they likely participated in antimicrobial activity by synergetic association with other active compounds. And this fact is important to be highlighted for all essential oils evaluated in this study.

\section{Conclusion}

The antimicrobial activity of essential oils of $L$. alba, $L$. sidoides, O. gratissimum, M. piperita and $Z$. officinale against $S$. agalactiae was confirmed in this study and the greatest inhibitory effect was obtained with $L$. sidoides essential oil. The results suggest that essential oils could be applied to treat bacterial fish diseases. However, further investigations are required to evaluate other strains of $S$. agalactiae and isolate the bioactive components of these oils and assess their individual and combined effects, as well as their toxicity and effective dose.

\section{Acknowledgments}

Dr. Marcelo Róseo de Oliveira from Embrapa Amazônia Ocidental, for assistance in distilling the essential oils and to Marcelly Cristina da Silva Santos, from Embrapa Agroindústria de Alimentos, for assistance in editing and reviewing the table of chemical composition of essential oils.

\section{Disclosure statement}

No potential conflicts of interest was reported by the authors.

\section{Funding}

This work was supported by the Embrapa - Brazilian Agricultural Research Corporation [\#MP2 02.12.01.020.00.00] and FINEP [\#DARPA project 01.09.0472.00]

\section{ORCID}

Cláudia Majolo (D) http://orcid.org/0000-0001-7554-9514

Fabiana Pilarski (D) http://orcid.org/0000-0003-3263-3235

Francisco Célio Maia Chaves (ID) http://orcid.org/0000-00024164-8511

Humberto Ribeiro Bizzo (D) http://orcid.org/0000-0001-53706478

Edsandra Campos Chagas (D) http://orcid.org/0000-0001-91709725

\section{References}

1. B. Austin and D.A. Austin, Bacterial fish pathogens. 4th edn. Springer-Science, Chichester, 552 (2007).

2. R. Salvador, E.E. Muller, J.C. Freitas, J.H. Leonhardt, L. G. Pretto and J.A. Dias, Isolation and characterization of Streptococcus spp group B in Nile tilapia (oreochromis niloticus) reared in hapas nets and earth nurseries in the northern region of Paraná State, Brasil. Cienc. Rural, 35, 1374-1378 (2005).

3. H.P.C. Figueiredo, D.O. Carneiro, F.C. Faria and G.M. Costa, Streptococcus agalactiae asociado a meningoencefalite e infecção sistêmica em tilápia do nilo (oreochromis niloticus) no Brasil. Arq Bras Medica Veterinary Zoo, 58, 678-680 (2006).

4. H.C.P. Figueiredo and C.A.G. Leal, Tecnologias aplicadas em sanidade de peixes. Reviews Bras Zootecn, 37, 8-14 (2008).

5. F. Pilarski, A.J. Rossini and P.S. Ceccarelli, Isolation and characterization of flavobacterium columnare from four tropical fish species in Brazil. Brazilian Journal Biologic, 68, 409-414 (2008).

6. J.J. Evans, P.H. Klesius, P.M. Gilbert, C.A. Shoemaker, M.A. Al Sarawi, J. Landsberg, R. Duremdez, A. Al Markouk and S. Al Kenzi, Characterization of $\beta$-haemolytic group B Streptococcus agalactiae in cultured sea bream, Sparus auratus L., and wild mullet, Liza klunzingeri (day), in Kuwait. Journal Fisheries Diseases, 25, 505-513 (2002).

7. U.P. Pereira, G.F. Mian, I.C.M. Oliveira, L.C. Benchetrit, G.M. Costa and H.C.P. Figueiredo, Genotyping of Streptococcus agalactiae strains isolated from fish, human and cattle and their virulence potential in Nile tilapia. Veterinary Microbiologic, 140, 186-192 (2010).

8. P. Orozova, V. Chikova and H. Najdenski, Antibiotic resistance of pathogenic for fish isolates of Aeromonas spp. Bulg Journal Agricultural Sciences, 16, 376-386 (2010).

9. M. Aravena-Román, T.J.J. Inglis, B. Henderson, T.V. Riley and B.J. Chang, Antimicrobial susceptibilities of Aeromonas strains isolated from clinical and environmental sources to 26 antimicrobial agents. Antimicrobial Agents Ch, 56, 1110-1112 (2012). 
10. R. Harikrishnan, C. Balasundaram and M.S. Heo, Impact of plant products on innate and adaptative immune system of cultured finfish and shellfish. Aquaculture (Amsterdam, Netherlands), 317, 1-15 (2011).

11. M. Reverter, N. Bontemps, D. Lecchini, B. Banaigs and P. Sasal, Use of plant extracts in fish aquaculture as an alternative to chemotherapy: current status and future perspectives. Aquaculture (Amsterdam, Netherlands), 433, 50-61 (2014).

12. M.E. Pascual, K. Slowing, E. Carretero, D.S. Mata and A. Villar, Lippia: traditional uses, chemistry and pharmacology: a review. Journal Ethnopharmacol, 76, 201214 (2001).

13. D.R. Oliveira, G.G. Leitão, S.S. Santos, H.R. Bizzo, D. Lopes, C.S. Alviano, D.S. Alviano and G.L. Suzana, Ethnopharmacological study of two Lippia species from oriximiná, Brazil. Journal Ethnopharmacol, 108, 103108 (2006).

14. E.S. Tavares, L.S. Julião, D. Lopes, H.R. Bizzo, C.L.S. Lage and S.G. Leitão, Analysis of the essential oil from leaves of three Lippia alba (mill.) N. E. Br. (verbenaceae) chemotypes cultivated on the same conditions. Reviews Bras Farmacogn, 15, 1-5 (2005).

15. A.L.B. Cunha, F.C.M. Chaves, H.R. Bizzo and A.M. Souza, Caracterização química do óleo essencial de erva-cidreira, nas condições de manaus, AM. Horticultural Bras, 30, S5780-S5784 (2012).

16. M.F. Souza, P.A. Gomes, I.T. Souza Júnior, M.M. Fonseca, C.S. Siqueira, L.S. Figueiredo and E.R. Martins, Influência do Sombreamento na produção de fitomassa e óleo essencial em alecrim-pimenta (Lippia sidoides cham.). R. Bras. Bioci, 5, 108-110 (2007).

17. M.R.A. Queiroz, A.C. Almeida, V.A. Andrade, T.S. Lima, E.R. Martins and L.S. Figueiredo, Avaliação da atividade antibacteriana do óleo essencial de Lippa origanoides frente à Staphylococcus sp. isolados de alimentos de origem animal. Reviews Bras Pl Medica, 16, 737-743 (2014).

18. M.A. Cunha, F.M.C. Barros, L.O. Garcia, A.P.L. Veeck, B.M. Heinzmann, V.L. Loro, T. Emanuelli and B. Baldisserotto, Essential oil of Lippia alba: a new anesthetic for silver catfish, Rhamdia quelen. Aquaculture (Amsterdam, Netherlands), 306, 403406 (2010).

19. L.L. Silva, D.T. Silva, Q.I. Garlet, M.A. Cunha, C.A. Mallmann, B. Baldisserotto, S.J. Longhi, A.M.S. Pereira and B.M. Heinzmann, Anesthetic activity of Brazilian native plants in silver catfish (Rhamdia quelen. Neotrop. Ichthyol., 11, 443-451 (2013).

20. C. Toni, A.G. Becker, L.N. Simões, C.G. Pinheiro, L. Silva, B.M. Heinzmann, B.O. Caron and B. Baldisserotto, Fish anesthesia: effects of the essential oils of Hesperozygis ringens and Lippia alba on the biochemistry and physiology of silver catfish (Rhamdia quelen). Fish Physiology and Biochemistry, 40, 701-714 (2014).

21. G.S.O. Hashimoto, F.M. Neto, M.L. Ruiz, M. Acchile, E.C. Chagas, F.C.M. Chaves and M.L. Martins, Essential oils of Lippia sidoides and mentha piperita against monogenean parasites and their influence on the hematology of Nile tilapia. Aquaculture (Amsterdam, Netherlands), 450, 182-186 (2016).
22. C. Majolo, S.I.B. Rocha, E.C. Chagas, F.C.M. Chaves and H.R. Bizzo, Chemical composition of Lippia spp. essential oil and antimicrobial activity against Aeromonas hydrophila. Aquac Researcher, 2016, 1-8 (2016).

23. B.V. Soares, L.R. Neves, M.S.B. Oliveira, F.C.M. Chaves, M.K.R. Dias, E.C. Chagas and M. TavaresDias, Antiparasitic activity of the essential oil of Lippia alba on ectoparasites of Colossoma macropomum (tambaqui) and its physiological and histopathological effects. Aquaculture (Amsterdam, Netherlands), 452, 107-114 (2016).

24. N. Mimica-Dukic, B. Bozin, M. Sokovic, B. Mihajlovic and M. Matavulj, Antimicrobial and antioxidant activities of three mentha species essential oils. Planta Medica, 69, 413-419 (2003).

25. A.D. Talpur, Mentha piperita (peppermint) as feed additive enhanced growth performance, survival, immune response and disease resistance of Asian seabass, lates calcarifer (bloch) against vibrio harveyi infection. Aquaculture (Amsterdam, Netherlands), 420-421, 71-78 (2014).

26. M. Mahboubi and N. Kazempour, Chemical composition and antimicrobial activity of peppermint (mentha piperita L.) essential oil. Songklanakarin Journal Sciences Technological, 36, 83-87 (2014).

27. D.F. Malheiros, P.O. Maciel, M.N. Videira and M. Tavares-Dias, Toxicity of the essential oil of mentha piperita in arapaima gigas (pirarucu) and antiparasitic effects on dawestrema spp. (monogenea). Aquaculture (Amsterdam, Netherlands), 455, 81-86 (2016).

28. F. Matos and F. Oliveira, Lippia sidoides cham.: farmacognosia, química e farmacologia. Reviews Bras Farm, 79, 84-87 (1998).

29. L.L. Silva, Q.I. Garlet, G.I. Koakoski, T.A. Oliveira, L.J. G. Barcellos, B. Baldisserotto, A.M.S. Pereira and B.M. Heinzmann, Effects of anesthesia with the essential oil of ocimum gratissimum L. in parameters of fish stress. Reviews Bras Pl Medica, 17, 215-223 (2015).

30. C.L. Boijink, C.A. Queiroz, E.C. Chagas, F.C.M. Chaves and L.A.K.A. Inoue, Anesthetic and anthelminthic effects of clove basil (ocimum gratissimum) essential oil for tambaqui (Colossoma macropomum. Aquaculture (Amsterdam, Netherlands), 457, 24-28 (2016).

31. F.J. Sutili, L.L. Silva, L.T. Gressler, E.K. Battisti, L.T. Gressler, B.M. Heinzmann, A.C.P. Vargas and B. Baldisserotto, Plant essential oils against Aeromonas hydrophila: in vitro activity and their use in experimentally infected fish. Journal Applications Microbiologic, 119, 47-54 (2015).

32. H. Lorenzi and F.J.A. Matos Plantas Medicinais No Brasil: Nativas E Exóticas, 2th ed. Editora Instituto Plantarum, Nova Odessa. F.J (2008).

33. M. Golebiowski, B. Ostrowski, M. Paszkiewicz, M. Czerwicka, J. Kumirska, L. Halinki, E. Malinski and P. Stepnowski, Chemical composition of commercially available essential oils from blackcurrant, ginger and peppermint. Chemical Natural Compd, 44, 794-796 (2008).

34. C.R. Kiran, A.K. Chakka, K.P. Padmakumari Amma, A. Nirmala Menon, M.M. Sree Kumar and V.V. Venugopalan, Essential oil composition of fresh ginger cultivars from North-East India. Journal Essent Oil Researcher, 25, 380-387 (2013). 
35. M. Agarwal, S. Walia, S. Dhingra and B.P. Khambay, Insect growth inhibition, antifeedant and antifungal activity of compounds isolated/derived from zingiber officinale roscoe (ginger) rhizomes. Pest Managed Sciences, 57, 289-300 (2001).

36. J.K. Kim, Y. Kim, K.M. Na, Y.J. Surh and T.Y. Kim, (6)-Gingerol prevents UVB-induced ROS production and COX-2 expression in vitro and in vivo. Free Radical Res, 41, 603-614 (2007).

37. A.D. Talpur, M. Ikhwanuddin and A.M.A. Bolong, Nutritional effects of ginger (Zingiber officinale roscoe) on immune response of Asian sea bass, lates calcarifer (bloch) and disease resistance against vibrio harveyi. Aquaculture (Amsterdam, Netherlands), 400-401, 46-52 (2013).

38. V.V. Panpatil, S. Tattari, N. Kota, C. Nimgulkar and K. Polasa, In vitro evaluation on antioxidant and antimicrobial activity of spice extracts of ginger, turmeric and garlic. Journal Pharmacogn Phytochem, 2, 143-148 (2013).

39. S.F. Bashir, S. Gurumayum and S. Kaur, In vitro antimicrobial activity and preliminary phytochemical screening of methanol, chloroform, and hot water extracts of ginger (Zingiber officinale). Asian Journal Pharmaceutical Clinical Researcher, 8, 176-180 (2015).

40. R.P. Adams Identification of Essential Oils Components by Gas Chromatography/Mass Spectrometry, 4th ed. Allured Publ. Corp, Carol Stream, IL (2007).

41. National Committee for Clinical Laboratory Standards, Methods for Dilution Antimicrobial Susceptibility Tests for Bacteria that Grow Aerobically Approved Standard M7-A6, Wayne, Pa, USA (2003).

42. H.N.H. Veras, F.F.G. Rodrigues, M.A. Botelho, I.R.A. Menezes, H.D.M. Coutinho and J.G.M. Costa, Enhancement of aminoglycosides and b-lactams antibiotic activity by essential oil of Lippia sidoides cham. and the thymol. Arabian Journal Chemical. (2013). doi:10.1016/j.arabjc.2013.10.0

43. C.P. Santos, T.C. Oliveira, J.A.O. Pinto, S.S. Fontes, E. M.O. Cruz, M.F. Arrigoni-Blank, T.M. Andrade, I.L. Matos, P.B. Alves, R. Innecco and A.F. Blank, Chemical diversity and influence of plant age on the essential oil from Lippia sidoides cham. germplasm. Industrial Crops Products, 76, 416-421 (2015).

44. I.H.N. Bassolé, A. Lamien-Meda, B. Bayala, S. Tirogo, C. Franz, J. Novak, R.C. Nebié and M.H. Dicko, Composition and antimicrobial activities of Lippia multiflora moldenke mentha $x$ piperita $L$. and ocimum basilicum L. essential oils and their major monoterpene alcohols alone and in combination. Molecules (Basel, Switzerland), 15, 7825-7839 (2010).

45. L.G. Matasyoh, J.C. Matasyoh, F.N. Wachira, M.G. Kinyua, A.W.T. Muigai and T.K. Mukiama, Chemical composition and antimicrobial activity of the essential oil of ocimum gratissimum l. growing in Eastern Kenya. African Journal Biotechnology, 6, 760-765 (2007).

46. G. Marcial, M.P. Lampasona, M.I. Veja, E. Lizarraga, C.I. Viturro, A. Slanis, M.A. Juarez, M.A. Elechosa and C.A.N. Catalan, Intraspecific variation in essential oil composition of the medicinal plant Lippia integrifolia (verbenaceae). evidence for five chemotypes. Phytochemistry, 122, 203-212 (2016).

47. F.J. Sutili, M.A. Cunha, R.E. Ziech, C.C. Krewer, C.C. Zeppenfeld, C.G. Heldwein, L.T. Gressler, B.M. Heinzmann, A.C. Vargas and B. Baldisserotto, Lippia alba essential oil promotes survival of silver catfish (Rhamdia quelen) infected with Aeromonas sp. Anais Da Academia Brasileira De Ciencias, 87, 95-100 (2015).

48. G.J. Heo, C.H. Kim, S.C. Park, M. Zoyza and G.W. Shim, Antimicrobial activity of thymol against pathogenic gram-negative bacteria of fishes. Philipp Journal Veterinary Medica, 49, 103-106 (2012).

49. O.D.L. Pessoa, C.B.M. Carvalho, J.O.V.L. Silvestre, M. C.L. Lima, R.M. Neto, F.J.A. Matos and T.L.G. Lemos, Antibacterial activity of the essential oil from Lippia aff. gracillis. Fitoterapia, 76, 712-714 (2005).

50. J. Henao, L.J. Muñoz, L. Padilha and E. Ríoz, Extraction and characterization of the essential oil of H.B.K. "Orégano de Lippia origanoides monte" cultivated at quindio and evaluation of antimicrobial activity. Reviews Invest University Quindio, 21, 82-86 (2010).

51. S.L.F. Sarrazin, R.B. Oliveira, L.E.S. Barata and R.H.V. Mourão, Chemical composition and antimicrobial activity of the essential oil of Lippia grandis schauer (verbenaceae) from the western Amazon. Food Chemistry, 134, 14741478 (2012).

52. A. Mathur, G.B.K.S. Prasad, N. Rao, P. Babu and V.K. Dua, Isolation and identification of antimicrobial compound from mentha piperita L. RASAYAN Journal Chemical, 4, 36-42 (2011).

53. D. Stanisavljević, S. Dordević, M. Milenković, M. Lazić, D. Velicković, N. Randelović and B. Zlatković, Antimicrobial and antioxidant activity of the essential oils obtained from mentha longifolia l. hudson, dried by three different techniques. Record Natural Products, 8, 61-65 (2014).

54. F.J. Sutili, L.C. Kreutz, M. Noro, L.T. Gressler, B.M. Heinzmann, A.C. Vargas and B. Baldisserotto, The use of eugenol against Aeromonas hydrophila and its effect on hematological and immunological parameters in silver catfish (Rhamdia quelen). Veterinary Immunology Immunop, 157, 142-148 (2014).

55. A.O. Gill and R.A. Holley, Mechanisms of bactericidal action of cinnamaldehyde against listeria monocytogenes and of eugenol against l. monocytogenes and lactobacillus sakei. Applications Environment Microbial, 70, 57505755 (2004).

56. Y. Sivasothy, W.K. Chong, A. Hamid, I.M. Eldeen, S.F. Sulaiman and K. Awang, Essential oils of Zingiber officinale var. rubrum theilade and their antibacterial activities. Food Chemistry, 124, 514-517 (2011).

57. J. Debbarma, P. Kishore, B.B. Nayak, N. Kannuchamy and V. Gudipati, Antibacterial activity of ginger, eucalyptus and sweet orange peel essential oil on fish-borne bacteria. Journal Food Processing Pres, 37, 1022-1030 (2013). 